\title{
FAKTOR-FAKTOR YANG MEMPENGARUHI STRUKTUR MODAL
}

\author{
Suharsono $^{1}$, Iwan Setiadi ${ }^{2}$ \\ Institute Teknologi dan Bisnis Ahmad Dahlan Jakarta ${ }^{1,2}$
}

\begin{abstract}
The purpose of this study was to determine the effect of profitability, liquidity, asset growth and company size on the capital structure. The population in this study used food and beverage sub-sector companies. The total population of this study was 70 samples. The technique used in sampling is purposive sampling. The hypothesis tested use the regression analysis. The analysis shows profitability, liquidity, and asset growth have a negative effect on DER. While the size of the company (size) has a positive effect on DER. The test results show that return on assets (ROA), Current Ratio (CR), Asset Growth (Growth) and Firm Size (Size) simultaneously have a significant effect on Debt to Equity Ratio (DER).
\end{abstract}

Keywords: Profitability; Liquidity; Asset Growth; Company Size; Capital Structure

\begin{abstract}
ABSTRAK
Tujuan penelitian untuk mengetahui pengaruh profitabilitas, likuiditas, pertumbuhan aset, dan ukuran perusahaan terhadap struktur modal. Populasi dalam penelitian ini menggunakan perusahaan sub sektor makanan dan minuman. Total populasi penelitian ini adalah 70 sampel. Teknik yang digunakan dalam pemgambilan sampel adalah purposive sampling. Pengujian hipotesis menggunakan analisis regresi. Hasil analisis menunjukkan profitabilitas, likuiditas, dan pertumbuhan aset berpengaruh negatif terhadap DER. Sedangkan ukuran perusahaan (size) berpengaruh positif terhadap $D E R$. Hasil pengujian menunjukan bahwa return on asset $(R O A)$, current ratio $(\mathrm{CR})$, pertumbuhan aset (Growth) dan ukuran perusahaan (Size) secara simultan berpengaruh terhadap debt to equity ratio $(D E R)$.
\end{abstract}

Kata Kunci: Profitabilitas; Likuiditas; Pertumbuhan Aset; Ukuran Perusahaan; Struktur Modal

\section{PENDAHULUAN}

Penelitian ini bertujuan untuk menguji pengaruh profitabilitas, likiuiditas, pertumbuhan aset dan ukuran perusahaan terhadap struktur modal. Profitabilitas diukur dengan return on assets (ROA), likuiditas diukur dengan current ratio (CR), pertumbuhan aset diukur dengan proksi growth ratio, ukuran perusahaan diukur dengan total aset. Adapun struktur modal diukur dengan debt to equity ratio (DER).

Profitabilitas adalah kemampuan perusahaan dalam memperoleh laba. Semakin besar profitabilitas, maka perusahaan akan memilih menggunakan keuntungan tersebut untuk membiayai kegiatan operasi sehingga akan mengurangi penggunaan utang (Dewi dan Sudiartha, 2017). Profitabilitas dapat mempengaruhi struktur modal (Brigham dan Houston, 2011:188) dalam (Maryanti, 2016). 
Menurut Gamaliel dan Sudjarni (2015) profitabilitas berpengaruh negatif terhadap struktur modal. Perusahaan yang memiliki tingkat profitabilitas yang tinggi, lebih memilih menggunakan tingkat profitabilitas tersebut untuk kegiatan operasi perusahaan daripada harus menambah tingkat utangnya.

Likuiditas adalah seberapa besar kemampuan perusahaan dalam mememenuhi kewajiaban jangka pendeknya pada saat jatuh tempo (Fahmi, 2015) dalam (Sutapa, 2018). Likuiditas berpengaruh positif terhadap struktur modal perusahaan. Semakin tinggi kemampuan perusahaan dalam mengembalikan kewajiban-kewajiban jangka pendeknya maka semakin likuid perusahaan tersebut sehingga kepercayaan dari kreditur meningkat dan mempermudah perusahaan memperoleh utang jangka panjang (Bhawa dan Dewi S, 2015).

Pertumbuhan aset dapat didefinisikan sebagai perubahan tahunan dari total aktiva. Menurut Adityana dan Ardiana (2014); Salim (2015); Riasita (2014) dalam (Dewi dan Sudiartha, 2017) bahwa tingkat pertumbuhan aset yang tinggi maka perusahaan akan meningkatkan sumber dana eksternal karena sumber dana internal tidak dapat mendukung tingkat pertumbuhan yang terdapat pada perusahaan.

Perusahaan dengan skala ukuran yang besar, akan berdampak pada naiknya harga saham. Perusahaan dengan ukuran yang besar dianggap lebih mampu memberikan tingkat pengembalian investasi sehingga akan mengurangi ketidakpastian investor terhadap perusahaan tersebut (Wahyuni dan Suryantini, 2014).

Ukuran perusahaan adalah gambaran perusahaan yang menunjukkan keberhasilan dari perusahaan yang dapat dilihat dari total aset yang dimiliki oleh perusahaan. Dengan semakin besar ukuran perusahaan maka semakin tinggi pula tingkat hutang yang digunakan, yang bertujuan untuk mengembangkan prospek perusahaan. Pernyataan ini didukung oleh Puspawardhani (2015).

Penelitian ini bertujuan untuk membuktikan seberapa besar profitabilitas, likuiditas, pertumbuhan aset, dan ukuran perusahaan berpengaruh terhadap struktur modal baik secara parsial maupun simultan.

\section{LITERATURE REVIEW}

\section{Signalling Theory}

Isyarat atau signal adalah suatu tindakan yang diambil perusahaan untuk memberikan petunjuk bagi investor tentang bagaimana menajemen memandang prospek perusahaan. Sinyal ini berfungsi mengenai apa yang sudah dilakukan manajemen untuk merealisasikan keinginan pemilik. Informasi yang dilakukan oleh perusahaan merupakan hal yang penting, karena pengaruhnya terhadap keputusan investasi dipihak luar perusahaan. Informasi sangat penting bagi investor dan pelaku bisnis karena informasi pada hakekatnya menyajikan keterangan, catatan, atau gambaran baik untuk keadaan masa lalu, saat ini maupun masa depan yang akan datang bagi kelangsungan hidup perusahaan dan bagaimana efeknya pada perusahaan (Brigham dan Joel Houaton, 2001) dalam (Khanafi, 2019).

Teori sinyal menyatakan bahwa terdapat informasi yang diperoleh dan bermanfaat pada suatu pengungkapan yang dapat menjadi sinyal bagi investor 
(penanam modal) dan pihak potensial lainnya dalam mengambil keputusan ekonomi. Suatu pengungkapan dikatakan mengandung informasi apabila dapat menimbulkan reaksi pasar, yaitu dapat berupa perubahan harga saham atau return saham (Aida dan Rahmawati, 2015).

Secara garis besar signaling theory erat kaitannya dengan ketersedian informasi. Laporan keuangan dapat digunakan untuk mengambil keputusan bagi para calon investor, laporan keuangan merupakan bagian terpenting dari analisis fundamental perusahaan. Pemeringkatan perusahaan yang sudah go-public lazimnya didasarkan pada analisis rasio keuangan ini. Analisis ini dilakukan untuk mempermudah interprestasi terhadap laporan keuangan yang telah disajikan oleh manajemen (Agus Kretarto, 2001:53) dalam (Feri, 2015).

\section{Struktur Modal}

Stuktur modal dapat didefinisikan kombinasi antara hutang dan modal sendiri (saham preferen dan saham biasa). Untuk memperoleh modal yang dibutuhkan, perusahaan perlu memperhatikan perimbangan antara hutang dan modal. Dalam hal ini perusahaan harus mengambil keputusan permodalan yang paling optimal sehingga menghasilkan kombinasi hutang dan modal yang akan mampu menghasilkan return yang paling maksimal (Wiyono dan Kusuma, 2017:173) dalam (Ahmad et all, 2017). Stuktur modal merupakan bauran pendanaan hutang jangka panjang dan ekuitas (modal) (Brealey et al., 2011: 600). Stuktur modal merupakan cara perusahaan untuk membentuk sisi kanan neraca yang terdiri dari modal dan hutang (Zani et al, 2013) dalam (Herawati, 2017).

Struktur modal dapat diukur dengan menggunakan rasio debt to equity ratio (DER). Rasio struktur modal ini menunjukkan hubungan antara jumlah hutang yang diberikan oleh para kreditur dengan jumlah modal sendiri yang diberikan oleh pemilik perusahaan. Debt to equity ratio sebagai ukuran yang dipakai dalam menganalisis laporan keuangan untuk memperlihatkan besarnya jaminan yang tersedia untuk kreditor.

\section{Profitabilitas}

Profitabilitas merupakan kemampuan perusahaan dalam memperoleh laba. Profitabilitas adalah rasio untuk mengukur efektivitas manajemen secara keseluruhan yang ditujukan oleh besar kecilnya tingkat keuntungan yang diperoleh dalam hubungannya dengan penjualan maupun investasi (Fahmi, 2015:80) dalam (Putri et al, 2016). Profitabilitas adalah rasio yang dapat digunakan untuk menilai kemampuan perusahaan dalam mencari keuntungan (Kasmir, 2014:196). Ukuran tingkat efektivitas manajemen suatu perusahaan dapat diukur menggunakan return on asset (ROA) (Brigham dan Houston, 2010:146). Menurut Damayanti (2013) dan Eviani (2015) dalam Cita (2019) perusahaan yang memiliki profitabilitas yang tinggi mengindikasikan bahwa perusahaan memiliki laba ditahan yang dapat digunakan sebagai sumber dana internal perusahaan. Apabila suatu perusahaan menggunakan laba ditahan sebagai penambah modalnya maka hal tersebut dapat mengurangi hutang yang dimiliki perusahaan. 
Perusahaan dengan tingkat pengembalian yang tinggi atas investasi menggunakan hutang yang relatif kecil (Brigham dan Houston, 2006) dalam (Sari, 2013:39). Profitabilitas yang diukur dengan return on asset (ROA) berpengaruh negatif terhadap hutang, dimana tingkat pengembalian yang tinggi memungkinkan untuk membiayai sebagian besar kebutuhan pendanaan yang dihasilkan secara internal, dengan alasan bahwa dana internal lebih murah dibanding biaya dana eksternal (Myers dan Majluf, 1984) dalam (Sari, 2013:39). Demikian menurut Hardanti dan Gunawan (2010); Indrajaya et al, (2011); dan Arini (2013). Semakin tinggi keuntungan yang diperoleh perusahaan menjadikan kebutuhan dana khususnya dari investor baik dalam jangka pendek maupun panjangnya makin kecil. Perusahaan dengan tingkat profitabilitas yang tinggi lebih cenderung menggunakan dana internal untuk keperluan operasi maupun investasinya. Perusahaan dengan tingkat keuntungan yang lebih besar memiliki sumber pendanaan internal yang lebih besar dan memiliki kebutuhan untuk melakukan pembiayaan investasi melalui pendanaan external yang lebih kecil, laba ditahan dapat digunakan sebagai tingkat pengembalian yang tinggi untuk kebutuhan dana. Berdasarkan hal tersebut penulis mengambil hipotesis sebagai berikut:

\section{H1: Profitabilitas berpengaruh negatif terhadap struktur modal.}

\section{Likuiditas}

Likuiditas adalah kemampuan perusahaan untuk membayar kemampuan financial jangka pendek tepat pada waktunya (Sartono, 2010:116) dalam (Bhawa dan Dewi, 2015). Rasio likuiditas biasa digunakan untuk mengukur kemampuan perusahaan dalam memenuhi kewajiban jangka pendeknya. Rasio ini dapat diukur dengan rasio current ratio. Current ratio adalah rasio antara aktiva lancar terhadap kewajiban lancar. Rasio ini menunjukkan kemampuan perusahaan untuk membayar kewajiban (hutang) jangka pendek dengan menggunakan aktiva lancarnya.

Pada umumnya aktiva lancar terdiri dari kas, surat berharga, piutang, dan persediaan. Sedangkan kewajiban lancar terdiri dari utang bank jangka pendek atau utang lainnya mempunyai jangka waktu kurang dari satu tahun. Apabila likuiditas mengalami kenaikan maka struktur modal akan mengalami penurunan secara tidak langsung. Hubungan negatif ini terjadi karena perusahaan yang memiliki likuiditas tinggi akan membayar utang-utangnya yang mengakibatkan tingkat penggunaan utang semakin menurun (Setyawan, Topowijono dan Nuzula, 2016).

Menurut Hardanti dan Gunawan (2010); Indrajaya et al (2011); Arini (2013); Prasetya dan Asandimitra (2014) menyatakan bahwa likuiditas berpengaruh negatif terhadap struktur modal. Perusahaan dengan menggunakan aktiva lancar dapat memenuhi kewajiban- kewajiban perusahaan dalam jangka pendek dari pada hutang jangka panjang. Sehingga dapat dikatakan semakin besar tingkat likuiditas perusahaan maka semakin kecil struktur modal perusahaan yang berarti semakin kecil penggunaan hutang (dana dari pihak eksternal). Ketersediaan kas dan aktiva lancar lainnya yang dimiliki perusahaan selain persediaan ternyata mampu digunakan untuk menutup hutang jangka pendek. Tertutupnya hutang jangka pendek berdampak pada menurunnyaproporsi hutang secara 
keseluruhan dalam struktur modal. Berdasarkan uraian diatas tersebut penulis mengambil hipotesis sebagai berikut:

\section{H2: Likuiditas berpengaruh negatif terhadap struktur modal.}

\section{Pertumbuhan Aset}

Pertumbuhan aset didefinisikan sebagai perubahan tahunan dari total aktiva.Variabel pertumbuhan aset juga dapat berpengaruh terhadap struktur modal dalam perusahaan. Tingkat pertumbuhan aset yang tinggi maka perusahaan akan meningkatkan sumber dana eksternal karena sumber dana internal tidak dapat mendukung tingkat pertumbuhan yang terdapat pada perusahaan (Adityana dan Ardiana, 2014). Hal ini konsisten dengan Sari (2013) yang menunjukkan bahwa grwoth berpengaruh positif terhadap DER. Berdasarkan uraian diatas tersebut penulis mengambil hipotesis sebagai berikut:

\section{H3: Pertumbuhan Aset berpengaruh positif terhadap struktur modal.}

\section{Ukuran Perusahaan}

Suatu pengungkapan dikatakan mengandung informasi apabila dapat menimbulkan reaksi pasar (Aida dan Rahmawati, 2015). Ukuran Perusahaan adalah suatu skala perusahaan yang dapat menggambarkan tingkat keberhasilan perusahaan tersebut. Perusahaan besar akan lebih memilih menggunakan sumber dana eksternal yang berasal dari utang dengan tujuan untuk kegiatan ekspansi perusahaan. Perusahaan besar dianggap lebih mudah memperoleh tambahan dana di pasar modal dibandingkan dengan perusahaan kecil karena perusahaan besar memiliki kemudahan akses dan ini berarti perusahaan besar memiliki fleksibilitas yang lebih besar pula. Jadi semakin besar ukuran perusahaan maka semakin besar pula kebutuhan perusahaan untuk memperoleh tambahan dana yang dapat berasal dari utang.

Ketika size perusahaan diproksikan dengan total asset yang dimiliki semakin besar, perusahaan dapat dengan mudah mendapatkan jaminan, dengan asumsi pemberi pinjaman percaya bahwa perusahaan mempunyai tingkat likuiditas yang cukup. Dengan demikian ukuran perusahaan berpengaruh positif terhadap stuktur modal (Ba- Abbad, 2012); (Indrajaya et all, 2011); (Sari, 2013); (Prasetya dan Asandimitra, 2014). Berdasarkan uraian diatas tersebut penulis mengambil hipotesis sebagai berikut:

\section{H4: Ukuran Perusahaan berpengaruh positif terhadap struktur modal.}

\section{METODE PENELITIAN}

Sampel dalam penelitian ini adalah perusahaan manufaktur sub sektor makanan dan minuman yang terdaftar di Bursa Efek Indonesia (BEI) tahun 20122018. Jenis data yang digunakan dalam penelitian ini adalah data sekunder yang berupa laporan tahunan perusahaan manufaktur sub sektor makanan dan minuman yang terdaftar di BEI. Data sekunder diperoleh dari situs www.idx.co.id dan dari website setiap perusahaan tersebut.

Variabel dependen struktur modal dalam penelitian ini diukur dengan:

$$
\mathrm{DER}=\frac{\text { otal Liabilities }}{\text { Total Equity }}
$$

DER = Debt to Equity Ratio 
Total Liabilities $\quad=$ Total Hutang

Total Equity = Total Ekuitas

Variabel independen yang pertama dalam penelitian ini adalah profitabilitas yang diukur dengan:

$$
\mathrm{ROA}=\frac{\text { Laba Bersih setalah Pajak }}{\text { Total Aset }}
$$

ROA = Return on Assets

Laba Bersih = Net Income

Total Aset $=$ Total Aktiva

Variabel independen yang kedua dalam penelitian ini adalah likuiditas yang diukur dengan:

$$
\mathrm{CR}=\frac{\text { tiva Lancar }}{\text { Hutang Lancar }}
$$

$\begin{array}{ll}\text { CR }(\text { Rasio Lancar }) & =\text { Current Ratio } \\ \text { Aktiva Lancar } & =\text { Current } \\ \text { Assets Hutang Lancar } & =\text { Current } \\ \text { Liabilities } & \end{array}$

Variabel independen yang ketiga dalam penelitian ini adalah pertumbuhan aset yang diukur dengan:

$$
\mathrm{PA}=\frac{\text { Total Aset } t-\text { Total Aset } \mathrm{t}-1}{\text { Total Aset } \mathrm{t}-1}
$$

PA = Pertumbuhan Aset

Total Aset $\mathrm{t}=$ Aset tahun periode saat ini

Total Aset $\mathrm{t}-1=$ Aset tahun periode

sebelumnya

Variabel independen yang keempat dalam penelitian ini adalah ukuran perusahaan yang diukur dengan:

$$
\mathrm{UP}=\mathrm{Ln} \text { (total aset) }
$$

$\begin{array}{ll}\text { UP } & =\text { Ukuran Perusahaan } \\ \text { Ln (total aset) } & =\text { Total aktiva }\end{array}$

\section{HASIL PENGUJIAN HIPOTESIS DAN PEMBAHASAN}

Tabel 1 memberikan gambaran statistik deskriptif dari setiap variabel khususnya minimum, maksimum, rata-rata, standar deviasi, dan jumlah perusahaan yang diamati.

Tabel 1. Statistik Deskiptif 


\section{Descriptive Statistics}

\begin{tabular}{|l|r|r|r|r|r} 
& N & Minimum & Maximum & Mean & Std. Deviation \\
\hline Return On Assets & 70 &, 03 &, 66 &, 1383 &, 12297 \\
\hline Current Rasio & 70 &, 51 & 8,91 & 2,2993 & 1,70964 \\
\hline Pertumbuhan Aset & 70 &,- 16 & 2,02 &, 1907 &, 28178 \\
\hline Ukuran Perusahaan & 70 & 12,43 & 18,39 & 15,0203 & 1,64032 \\
\hline Debt to Equity Rasio & 70 &, 03 & 1,74 &, 4477 &, 43845 \\
\hline Valid N (listwise) & 70 & & & & \\
\hline
\end{tabular}

9. Uji Asumsi Klasik

Penelitian ini memenuhi seluruh pengujian asumsi klasik. Dalam penlitian ini uji normalitas Kolmogorov-Smirnov adalah 0,066 dan signifikansi 0,200, nilai signifikansi tersebut jauh diatas 0,05 yang mengartikan bahwa data residual terdistribusi dengan normal dan model regresi dapat dipakai untuk pengujian selanjutnya. Selain itu tidak terjadi autokorelasi dan heteroskedastisitas serta tidak terjadi multikolonieritas antar variabel independen.

10. Analisis Regresi Berganda

Menurut Priyatno (2014:148) menyatakan bahwa analisis regresi linier berganda digunakan untuk mengetahui pengaruh atau hubungan secara linier antara dua atau lebih variabel independen dengan satu variabel dependen. Analisis regresi berganda dilakukan untuk mengetahui pengaruh ROA, CR, Growth dan Size terhadap DER.

$$
\mathrm{DER}=\alpha+\beta 1 \mathrm{ROA}+\beta 2 \mathrm{CR}+\beta 3 \text { Growth }+\beta 4 \text { Size }+\mathrm{e}
$$
berikut ini:

Hasil analisis regresi linier berganda dapat dilihat pada tabel 2 Tabel 2. Hasil Perhitungan Regresi

\begin{tabular}{lllll} 
Variabel & Predicted Sign & Coefficient & p-value & \\
\cline { 1 - 3 } Intercept & & $-10,666$ & 0,000 & \\
Ln_ROA & - & $\mathbf{0 , 8 2 9}$ & $\mathbf{0 , 0 0 0}$ & $* * *$ \\
Ln_CR & - & $\mathbf{0 , 7 7 4}$ & $\mathbf{0 , 0 0 0}$ & $* * *$ \\
Ln_Growth & + & $\mathbf{0 , 4 5 3}$ & $\mathbf{0 , 0 0 2}$ & $* *$
\end{tabular}

$*, * *, * * *$ menunjukan koefisien signifikan pada 0,$1 ; 0,05 ; 0,01$

$\begin{array}{ll}\text { ROA } & : \text { Return on Asset } \\ \text { CR } & : \text { Current Ratio } \\ \text { Growth } & : \text { Pertumbuhan aset } \\ \text { Size } & : \text { Ukuran perusahaan } \\ \text { DER } & : \text { Debt to Equity Ratio }\end{array}$

Berdasarkan Tabel 2 maka hasil pengujian analisis regresi berganda dapat dijelaskan melalui persamaan sebagai berikut ini:

LnDER $=-10,666-0,829$ LnROA - 0,774 LnCR + 0,453 LnGrowth + 3,235 LnSize + e 
11. Uji Koefisien Determinasi

Tabel 3. Hasil Uji Koefisien Determinasi

\begin{tabular}{|c|r|r|r|r|}
\hline $\mathrm{R}$ & R Square & $\begin{array}{c}\text { Adjusted R } \\
\text { Square }\end{array}$ & $\begin{array}{c}\text { Std. Error of the } \\
\text { Estimate }\end{array}$ & Durbin-Watson \\
\hline 0,705 & 0,498 & 0,467 & 0,89427 & 1,649 \\
\hline
\end{tabular}

Berdasarkan tabel 3 dapat dilihat hasil analisis regresi secara keseluruhan menunjukan nilai (Adjusd R Square) sebesar 0467 atau 46,7\%. Nilai ini menunjukkan bahwa hanya sekitar $46,7 \%$ variabel terikat DER yang dipengaruhi oleh variabel bebas ROA, CR, Growth dan Size. Selebihnya sebesar 53,3\% dijelaskan oleh variabel independen lain yang tidak diteliti dalam penelitian ini. Semakin kecil Standard Error of the Estimate (SEE) akan membuat model regresi semakin tepat dalam memprediksi variabel dependen yaitu DER dengan variabel independennya.

12. Uji F

\begin{tabular}{|c|c|c|c|c|c|c|}
\hline \multicolumn{7}{|c|}{$\begin{array}{c}\text { Tabel 4. Hasil Uji F } \\
\text { ANOVA }^{\mathrm{a}}\end{array}$} \\
\hline Model & & $\begin{array}{l}\text { Sum of } \\
\text { Squares }\end{array}$ & $\mathrm{df}$ & Mean Square & $\mathrm{F}$ & Sig. \\
\hline \multirow[t]{3}{*}{1} & Regression & 51.472 & 4 & 12.868 & 16.091 & $.000^{b}$ \\
\hline & Residual & 51.982 & 65 & .800 & & \\
\hline & Total & 103.454 & 69 & & & \\
\hline
\end{tabular}

Berdasarkan tabel 4, hasil nilai signifikannya adalah $0,000<0,05$, maka dari itu dapat dilihat dari persamaan variabel bebas yakni ROA, CR, Growth dan Size secara bersama-sama berpengaruh terhadap DER.

13. Uji t

\begin{tabular}{lllll}
\multicolumn{5}{c}{ Tabel 5. Hasil Uji t } \\
Variabel & Predicted Sign & Coefficient & $t$ & p-value \\
\hline Intercept & & $-10,666$ & $-3,850$ & 0,000 \\
Ln_ROA & - & $\mathbf{0 , 8 2 9}$ & $\mathbf{5 , 6 4 5}$ & $\mathbf{0 , 0 0 0}$ \\
Ln_CR & - & $\mathbf{0 , 7 7 4}$ & $\mathbf{4 , 4 7 9}$ & $\mathbf{0 , 0 0 0}$ \\
Ln_Growth & + & $\mathbf{0 , 4 5 3}$ & $\mathbf{3 , 2 4 6}$ & $\mathbf{0 , 0 0 2}$ \\
Ln_Size & + & $\mathbf{3 , 2 3 5}$ & $\mathbf{3 , 1 3 3}$ & $\mathbf{0 , 0 0 3}$ \\
\hline
\end{tabular}

$\begin{array}{ll}\text { ROA } & : \text { Return on Asset } \\ \text { CR } & : \text { Current Ratio } \\ \text { Growth } & : \text { Pertumbuhan aset } \\ \text { Size } & \text { : Ukuran perusahaan } \\ \text { DER } & : \text { Debt to Equity Ratio }\end{array}$


Berdasarkan Tabel 5, variabel ROA memiliki nilai t_hitung sebesar -5,645 dengan nilai signifikansi 0,000 . Nilai signifikansi lebih kecil dari 0,05 menunjukan bahwa variabel ROA berpengaruh negatif terhadap DER. Dengan demikian H1 diterima. Variabel CR memiliki nilai t_hitung sebesar -4,479 dengan nilai signifikansi 0,000 . Nilai signifikansi lebih kecil dari 0,05 menunjukan bahwa variabel CR berpengaruh negatif terhadap DER. Dengan demikian H2 diterima. Variabel growth memiliki nilai t_hitung sebesar 3,246 dengan nilai signifikansi 0,002 . Nilai signifikansi lebih kecil dari 0,05 menunjukan variabel growth berpengaruh positif terhadap DER. Dengan demilian H3 diterima. Variabel size memiliki nilai t_hitung sebesar 3,133 dengan nilai signifikansi 0,003 . Nilai signifikansi lebih kecil dari 0,05 menunjukan variabel size berpengaruh positif signifikan terhadap DER. Dengan demilian H4 diterima.

Dalam pengujian yang dilakukan, pengaruh ROA terhadap DER dilihat berdasarkan hasilnya nilai t-hitung sebesar $-5,645$ dan nilai signifikansi adalah 0,000 dan nilai signifikasi tersebut lebih kecil dari 0,05 . Hal ini mengartikan bahwa ROA berpengaruh negatif terhadap DER. Hasil penelitian ini konsisten dengan Gunawan dan Hardanti (2010), Indrajaya et al, (2011), Arini (2013), Insiroh (2014), Bhawa dan Dewi (2015) dan Widiyanti et al (2016) yang menunjukkan bahwa profitabilitas berpengaruh negatif terhadap struktur modal. Profitabilitas merupakan hasil akhir dari sejumlah kebijakan dan keputusan manajemen.

Pengaruh CR terhadap DER dilihat berdasarkan hasilnya nilai t-hitung sebesar -4,479 dan nilai signifikasinya adalah 0,000 dan nilai signifikasi tersebut lebih kecil dari 0,05. Hal ini mengartikan bahwa CR berpengaruh negatif terhadap DER. Hasil penelitian ini konsisten dengan Gunawan dan Hardianti (2010), Indrajaya et al, (2011), Arini (2013), Prasetya dan Asandimitra (2014), Santoso dan Priantinah (2016) dan Widiyanti et al, (2016) menunjukkan bahwa CR berpengaruh negatif terhadap DER. Likuiditas memiliki pengaruh terhadap struktur modal dikarenakan, tingkat likuiditas suatu perusahan mempengaruhi besar dan kecilnya stuktur modal pada perusahaan tersebut. Apabila suatu perusahaan memiliki tingkat likuiditas yang tinggi, maka hal ini mencerminkan bahwa aktiva lancar yang dimiliki perusahaan lebih besar dibandingkan hutang (kewajiban) yang harus dipenuhi. Jumlah aktiva lancar yang besar menyebabkan perusahaan mampu memenuhi kebutuhan investasi serta dapat membayar kewajibannya dengan tepat pada waktunya. Sehingga dengan meningkatnya likuiditas akan menurunkan jumlah struktur modal.

Berdasarkan tabel 5, pengaruh ROA terhadap DER mempunyai nilai thitung sebesar $-5,645$ dan nilai signifikansi adalah 0,000 dan nilai signifikasi tersebut lebih kecil dari 0,05 . Hal ini mengartikan bahwa ROA berpengaruh negatif terhadap DER. Hasil penelitian ini konsisten dengan Gunawan dan Hardanti (2010), Indrajaya et al, (2011), Arini (2013), Insiroh (2014), Bhawa dan Dewi (2015) dan Widiyanti et al (2016) yang menunjukkan bahwa profitabilitas berpengaruh negatif terhadap struktur modal.

Pengaruh CR terhadap DER dilihat berdasarkan hasilnya nilai t-hitung sebesar -4,479 dan nilai signifikasinya adalah 0,000 dan nilai signifikasi tersebut 
lebih kecil dari 0,05. Hal ini menunjukkan bahwa CR berpengaruh negatif terhadap DER. Hasil penelitian ini konsisten dengan Gunawan dan Hardianti (2010), Indrajaya et al, (2011), Arini (2013), Prasetya dan Asandimitra (2014), Santoso dan Priantinah (2016) dan Widiyanti et al, (2016). Likuiditas memiliki pengaruh terhadap struktur modal dikarenakan tingkat likuiditas suatu perusahan mempengaruhi besar kecilnya stuktur modal pada perusahaan tersebut. Perusahaan dengan tingkat likuiditas yang tinggi, mencerminkan bahwa aktiva lancar yang dimiliki perusahaan lebih besar dibandingkan hutang yang harus dipenuhi. Sehingga perusahaan mampu memenuhi kebutuhan investasi serta dapat membayar kewajiban dengan tepat waktu. Karena itu peningkatan likuiditas pada perusahaan akan menurunkan jumlah struktur modal.

Pengaruh growth terhadap DER dilihat berdasarkan hasilnya nilai t-hitung sebesar 3,246 dan nilai signifikansi adalah 0,002 dan nilai probabilitas tersebut lebih kecil dari 0,05 . Hal ini mengartikan bahwa growth berpengaruh positif terhadap DER. Hasil penelitian ini konsisten dengan Sari (2013). Dengan suatu tingkat pertumbuhan aset yang tinggi maka perusahaan akan meningkatkan sumber dana eksternal karena sumber dana internal tidak dapat mendukung tingkat pertumbuhan yang terdapat pada perusahaan.

Dalam pengujian yang dilakukan, pengaruh ukuran perusahaan (size) terhadap DER dilihat berdasarkan hasilnya nilai t-hitung sebesar 3,133 dan nilai probabilitasnya adalah 0,003 dan nilai probabilitas tersebut lebih kecil dari 0,05. Hal ini mengartikan bahwa variabel ukuran perusahaan (size) berpengaruh positif terhadap DER. Hasil penelitian ini konsisten dengan Indrajaya et al, (2011), Sari (2013), Prasetya dan Asandimitra (2014), Wiagustuni dan Pertamawati (2015), Santoso dan Priantinah (2016) dan Marfuah dan Nurlaela (2017). Perusahaan besar akan lebih memilih menggunakan sumber dana eksternal yang berasal dari utang dengan tujuan untuk kegiatan ekspansi perusahaan. Perusahaan besar dianggap lebih mudah memperoleh tambahan dana di pasar modal dibandingkan dengan perusahaan kecil. Perusahaan besar memiliki kemudahan akses dan ini berarti perusahaan besar memiliki fleksibilitas yang lebih besar pula. Jadi semakin besar ukuran perusahaan maka semakin besar pula kebutuhan perusahaan untuk memperoleh tambahan dana yang dapat berasal dari utang. Ketika size perusahaan diproksikan dengan total asset yang dimiliki semakin besar, perusahaan dapat dengan mudah mendapatkan jaminan, dengan asumsi pemberi pinjaman percaya bahwa perusahaan mempunyai tingkat likuiditas yang cukup.

Hasil pengujian menunjukan bahwa return on asset (ROA), current ratio (CR), pertumbuhan aset (growth) dan ukuran perusahaan (size) secara simultan berpengaruh terhadap debt to equity ratio (DER). Hal ini ditunjukan dengan nilai signifikansi $\mathrm{F}=0,000$ (lebih kecil dari 0,05). Hasil penelitian ini sejalan dengan Gunawan dan Hardianti (2010), Indrajaya et al, (2011), Arini (2013), Insiroh (2014), Bhawa dan Dewi (2015) dan Widiyanti et al (2016), Sari (2013) yang menunjukan bahwa ROA, CR, growth dan size berpengaruh terhadap DER.

\section{KESIMPULAN, KETERBATASAN DAN SARAN}

Pada penelitian ini dapat disimpulkan bahwa profitabilitas yang diukur dengan return on assets (ROA) dan likuiditas yang diukur dengan current ratio (CR) berpengaruh negatif terhadap struktur modal. Pertumbuhan aset (growth) 
dan ukuran perusahaan berpengaruh positif terhadap struktur modal. Untuk peneliti selanjutnya penelitian ini diharapkan bisa menjadi gambaran serta untuk menambah referensi, wawasan, memberikan tambahan pengetahuan dan diharapkan dapat dijadikan bahan untuk pengembangan penelitian selanjutnya, dengan tema dan variabel yang berbeda agar mampu menciptakan penelitianpenelitian baru yang lebih baik. Perusahaan yang digunakan sebagai sampel masih terbatas pada perusahaan manufaktur sektor makanan dan minuman, sehingga pada penelitian selanjutnya diharapkan memperluas sampel perusahaan agar lebih tergeneralisasi.

\section{DAFTAR PUSTAKA}

Adityana, Ida Bagus Gede Nickho Sabo, Putu Agus Ardiana. 2014. Pengaruh Ukuran Perusahaan, Risiko Bisnis, Pertumbuhan Aset, Profitabilitas dan Likuiditas pada Struktur Modal. E-Jurnal Akunatansi Universitas Udayana, 9(3), hal: $788-802$

Ahmad, G. N., Lestari, R., \& Dalimunthe, S. 2017. Analysis of Effect of Profitability, Assets Structure, Size of Companies, and Liquidity to Capital Structures in Mining Companies Listed in Indonesia Stock Exchange period 20122015. JRMSI-Jurnal Riset Manajemen Sains Indonesia, 8(2), 339-354.

Aida, R. N., \& Rahmawati, E. 2015. Pengaruh modal intelektual dan pengungkapannya terhadap nilai perusahaan: Efek intervening kinerja perusahaan. Journal of Accounting and Investment, 16(2), 96-109.

Arini, F. 2013. Pengaruh Likuiditas, Ukuran Perusahaan, Struktur Aktiva, Profitabilitas, dan Pertumbuhan Penjualan Terhadap Struktur Modal (Studi Pada Perusahaan Pertambangan yang Terdaftar di Bursa Efek Indonesia). Jurnal Ilmiah Mahasiswa FEB, 2(2).

Bhawa, I. B. M. D. 2015. Pengaruh Ukuran Perusahaan, Likuiditas, Profitabilitas, dan Risiko Bisnis terhadap Struktur Modal Perusahaan Farmasi. EJurnal Manajemen, 4(7).

Ba-Abbad, K., Zaluki, A., \& Ashikkin, N. 2012. The determinants of capital structure of Qatari listed companies. International Journal of Academic Research in Accounting, Finance and Management Sciences, 2(2), 93-108.

Cita Ken Maharsi, S. 2019. Pengaruh Profitabilitas, Likuiditas, Pertumbuhan Penjualan, Struktur Aset, dan Kebijakan Dividen terhadap Struktur Modal (Doctoral dissertation, Universitas Multimedia Nusantara).

Dewi, D. A. I. Y. M., \& Sudiartha, G. M. 2017. Pengaruh Profitabilitas, Ukuran Perusahaan, dan Pertumbuhan Aset terhadap Struktur Modal dan Nilai Perusahaan. E-Jurnal Manajemen, 6(4), 2222-2252.

Feri, M. 2015. Pengaruh Rasio Profitabilitas terhadap Perubahan Harga Saham pada Perusahaan Sektor Properti yang Listing di Bursa Efek Indonesia periode 2008-2012. Jurnal Ilmu Manajemen (JIM), 2(4).

Gamaliel, J., \& Sudjarni, L. K. 2015. Pengaruh Profitabilitas, Ukuran Perusahaan dan Struktur Aktiva terhadap Struktur Modal pada Perusahaan Transportasi di Bursa Efek Indonesia. E-Jurnal Manajemen, 4(1). 
Hardanti, S., \& Gunawan, B. 2016. Pengaruh Size, Likuiditas, Profitabilitas, Risiko, dan Pertumbuhan Penjualan terhadap Struktur Modal. Journal of Accounting and Investment, 11(2), 148-165.

Indrajaya, G., \& Setiadi, R. 2011. Pengaruh Struktur Aktiva, Ukuran Perusahaan, Tingkat Pertumbuhan, Profitabilitas dan Risiko Bisnis terhadap Struktur Modal: Studi Empiris pada Perusahaan Sektor Pertambangan yang Listing di Bursa Efek Indonesia periode 2004-2007. Akurat Jurnal Ilmiah Akuntansi, 2(06).

Insiroh, L. 2014. Pengaruh Profitabilitas, Ukuran Perusahaan, Pertumbuhan Aset, dan Struktur aset terhadap Struktur Modal. Jurnal Ilmu Manajemen (JIM), 2(3).

Khanafi, S. S. M. 2019. Penagruh Permodalan, Kualitas Aset, Net Profit Margin, Rentabilitas, Likuiditas dan Risk Profil terhadap Kinerja Keungan Bank (Studi Empiris pada Perusahaan Perbankan Syariah tahun 2014-2018) (Doctoral dissertation, Skripsi, Universitas Muhammadiyah Magelang).

Marfuah, S. A., \& Nurlaela, S. 2017. Pengaruh Ukuran Perusahaan, Pertumbuhan Asset, Profitabilitas dan Pertumbuhan Penjualan terhadap Struktur Modal Perusahaan Cosmetics and Household di Bursa Efek Indonesia. Jurnal Akuntansi dan Pajak, 18(01).

Maryanti, E. 2016. Analisis Profitabilitas, Pertumbuhan Perusahaan, Pertumbuhan Penjualan dan Struktur Aktiva terhadap Struktur Modal pada Perusahaan Sektor Industri Barang Konsumsi yang terdaftar di Bursa Efek Indonesia (Studi Empiris pada Perusahaan Manufaktur yang Terdaftar di Bursa Efek Indonesia tahun 2012-2014). Riset Akuntansi dan Keuangan Indonesia, 1(2), 143-151.

Prasetya, T. B. dan Asandimitra, N. 2014. Pengaruh Profitabilitas, Ukuran Perusahaan, Growth Opportunity, Likuiditas, Struktur Aset, Resiko Bisnis, dan Non Debt Tax Shield terhadap Struktur Modal pada Perusahaan Sub- Sektor Barang Konsumsi, 1341-1348.

Duwi Priyatno, 2014, SPSS 22 Pengolah Data Terpraktis, Andi Publisher, Yogyakarta

Putri, R. H., Zahroh, Z. A., \& Wi Endang NP, M. G. 2016. Pengaruh Rasio Likuiditas dan Rasio Profitabilitas terhadap Nilai Perusahaan (Studi pada Perusahaan Sektor Industri Barang Konsumsi yang terdaftar di BEI tahun 20122014. Jurnal Administrasi Bisnis, 38(2), 38-45.

Santoso, Y., \& Priantinah, D. 2016. Pengaruh Profitabilitas, Ukuran Perusahaan, Struktur Aktiva, Likuiditas dan Growth Opportunity terhadap Struktur Modal Perusahaan. Jurnal Profita: Kajian Ilmu Akuntansi, 4(4).

Sari, D. V., \& Haryanto, A. M. 2013. Pengaruh Profitabilitas, Pertumbuhan Aset, Ukuran Perusahaan, Struktur Aktiva dan Likuiditas terhadap Struktur Modal pada Perusahaan Manufaktur di Bursa Efek Indonesia tahun 2008-2010 (Doctoral dissertation, Fakultas Ekonomika dan Bisnis).

Setyawan, A. Topowijono, dan Nuzula. 2016. Pengaruh Firm Size, Growth Opportunity, Profitability, Business Risk, Effective Tax Rate, Asset Tangibility, Firm Age, dan Liquidity terhadap Struktur Modal Perusahaan (Studi pada Perusahaan Sektor Property dan Real Estate yang terdaftar di BEI tahun 20092014). Jurnal Administrasi Bisnis, 31(1). 
Sutapa, I. N. 2016. Pengaruh rasio dan kinerja keuangan terhadap harga saham pada indeks LQ45 di Bursa Efek Indonesia (BEI) periode 2015-2016. KRISNA: Kumpulan Riset Akuntansi, 9(2), 11-19.

Sutomo, I. 2014. Analisis rasio profitabilitas untuk menilai kinerja keuangan pada PT Niagaraya Kreasi Lestari Banjarbaru. Jurnal Kindai, 10.

Wahyuni, I. A. T., \& Suryantini, N. P. S. 2014. Pengaruh Ukuran Perusahaan, Profitabilitas dan Penghematan Pajak terhadap Struktur Modal. EJurnal Manajemen, 3(5).

Widayanti, L. P., Triaryati, N., \& Abundanti, N. 2016. Pengaruh profitabilitas, tingkat pertumbuhan perusahaan, likuiditas, dan pajak terhadap struktur modal pada sektor pariwisata. E-Jurnal Manajemen, 5(6).

Yuvita Herawati, V. I. N. C. E. N. C. I. A. 2017. Pengaruh Corporete Gorvanence Preception Iindex (CGPI), Struktur Kepemilikan, Ukuran Perusahaan,, Corporate Social Responbility, dan Struktur Modal terhadap Kinerja Keuangan (Studi Empiris pada Perusahaan yang terdaftar di BEI periode 20122015) (Doctoral dissertation, IIB DARMAJAYA). 